\title{
TREND BARU ISLAM AWAL ABAD 21
}

\author{
Arki Auliahadi \\ IAIN Bukittinggi \\ Mina Zahara \\ UIN Sultan Thaha Saifuddin Jambi \\ arkilpm@gmail.com
}

\begin{abstract}
Abstrak
Pembahasan dalam tulisan ini merupakan sebuah paparan tentang keadaan Islam di Indonesia awal abad ke 21 atau millenium ke 3. Pada waktu tersebut, keinginan umat Islam untuk kembali kepada ajaran Islam sudah sangat kuat sehingga muncul banyak pemikir Islam dan organisasi keislaman yang berdakwah mengajak masyarakat dengan paham keislamannya. Hal ini menimbulkan suatu dinamika tersendiri dalam perkembangan Islam di Indonesia. Tujuan penulisan ini untuk mendeskripsikan bagaimana keadaan dan perkembangan Islam pada awal abad ke 21 di Indonesia, munculnya cendekiawan Muslim dan organisasi-organisasi keislaman. Mengetahui seluk beluk bagaimana organisasi itu muncul dan bagaimana pandanganya tentang islam saat ini. Karena minimnya masyarakat tentang Islam maka melalui organisasi inilah mereka membahas secara rinci perkembangan islam pada abad 21, walaupun dalam pembahasan mereka itu banyak konflik interen maupun eksteren. Tetapi tidak semua organisasi menimbulkan konflik terkadang ada diantara pendapat mereka yang membuat masyarakat ingin lebih memperdalam islam. Dan keinginan untuk mengembalikan Islam Sejati sesuai Al-Qur'an dan Sunnah.
\end{abstract}

Kata Kunci: cendekiawan, Indonesia, Islam, organisasi,

\section{PENDAHULUAN}

Indonesia dikenal sebagai bangsa Muslim terbesar di dunia, artinya mayoritas penduduk Indonesia beragama Islam, sekalipun tidak disebutkan dalam konstitusi sebagai negara agama. Terlepas dari argumen-argumen intelektual sebagian besar rakyat dalam memahami ajaran Islam, baik karena faktor sejarah ataupun kultural, Islam di Indonesia adalah suatu agama yang hidup dan vital, yang kini sedang terlibat dalam proses tranformasi dari posisi kuantitas ke posisi kualitas. Dengan kata lain, Islamisasi di Indonesia bukanlah suatu produk sejarah yang telah rampung, tetapi merupakan proses yang berkelanjutan (Maarif, 1985: 1)

Menurut Soedjatmoko, sebagaimana dikutip oleh Syafii Maarif, berpendapat bahwa proses Islamisasi sesungguhnya secara kualitatif belum pernah mencapai tingkatnya yang sempurna, maka Islam sebegitu jauh belum mampu menggantikan sepenuhnya kepercayaan-kepercayaan dan tradisi-tradisi kultural lokal sebagai basis bagi organisasi sosial. Karena kesadaran akan pentingnya menutup jurang antara 
Islam masa lampau dan cita-cita Islam pada masa moderen, maka intensitas kegiatan dakwah Islam semakin disemangatkan dan semakin meluas, terutama di kalangan anak muda Indonesia (Maarif, 1985: 3)

Prospek Islam di Indonesia nampaknya banyak bergantung pada kemampuan intelektual Muslim, para ulama dan pemimpin-pemimpin Islam yang lain juga memahami realitas masyarakat mereka, kemudian menghubungkannya dengan ajaran-ajaran Islam sebagaimana tersurat dan tersirat dalam Alquran dan Hadits Nabi. (Maarif, 1985: 9) Oleh karena itu, perlu kita melihat bagaimana proses transformasi yang terjadi dalam Islam di Indonesia, dari kuantitas menuju kualitas. Hal ini menjadi trend baru Islam abad 20 hingga abad sekarang ini (abad 21).

\section{KAJIAN TERDAHULU}

Mengenai kajian terdahulu yang relevan dengan tulisan ini, banyak sekali tersebar di dunia maya berupa artikel-artikel. Tapi ada satu buku yang memiliki kedekatan dengan tulisan ini, yaitu buku yang ditulis oleh Prof. Dr. Bambang Cipto, M.A. yang berjudul Dunia Islam dan masa depan hubungan Internasional Abad 21.(Cipto, 2011: 21) Dalam buku ini menjelaskan tren bentuk sekuler dan desekulerisasi pada dunia Islam secara umum khususnya di Indonesia. Hal ini menjadi salah satu kontribusi bagi tulisan ini dalam melihat sekuler di Indonesia. Namun yang menjadi perbedaannya adalah sisi historis yang menjadi kajian dalam tulisan ini.

\section{METODE PENELITIAN}

Tulisan dalam ini merupakan penelitian kualitatif. Penelitian kualitatif adalah salah satu bentuk penelitian yang bertujuan untuk mendapatkan pemahaman tentang kenyataan melalui proses berpikir induktif. karakteristik dari metode kualitatif adalah usaha mengungkap berbagai keunikan yang terdapat dalam individu, kelompok, masyarakat atau organisasi dalam kehidupan sehari-hari secara menyeluruh, rinci, dalam, dan dapat dipertanggungjawabkan secara ilmiah. Kajian dalam penelitian ini mengarah kepada kajian sejarah dan menggunakan pendekatan penelitian sejarah yang terdiri dari empat tahapan (Kartodirjo, 2003: 23), yaitu: heuristik berupa pengumpulan bahan/sumber, kritik sumber berupa kritik intern-ekstern, interpretasi atau sintesis, dan penulisan dalam bentuk historiografi.

Heuristik merupakan tahap awal dalam penelitian sejarah yaitu pencarian dan pengumpulan sumber-sumber sejarah. Untuk penelitian ini, sumber-sumber dikumpulkan dari studi pustaka. Tahapan kedua adalah kritik sumber, yang dapat dibagi atas kritik ektern dan intern. Kritik ekstern dilakukan untuk mencari otentisitas arsip dan dokumen yang sudah didapatkan. Sedangkan kritik intern dilakukan terhadap isi dokumen yang otentik tersebut untuk mendapat kevalidan data yang dikandungnya. Tahap ketiga adalah analisis dan sintesis data. Fakta yang diperoleh lalu dianalisis dengan menggunakan analisis prosesual dan struktural. 


\section{PEMBAHASAN}

Jeritan untuk kembali kepada Islam sejati dengan Alquran dan sunnah sebagai dasarnya merupakan tema sentral dalam pemikiran modernis Islam (Kartodirjo, 2003: 40),. Menurut Ahmad W. Pratiknya, salah satu fenomena yang cukup menonjol dalam hal ini adalah hangatnya pembicaraan tentang cendekiawan Muslim. Fenomena mengenai hal ini muncul disebabkan oleh beberapa alasan, antara lain:

a. Pertama, makin dirasa pentingnya peran cendekiawan dalam tahapan pembangunan nasional dewasa ini, dengan demikian posisi cendekiawan makin diperhitungkan dibanding masa-masa lampau.

b. Kedua, timbulnya kesadaran baru di kalangan cendekiawan Muslim sendiri, kesadaran untuk mengaktualkan potensinya ditengah-tengah keterbelakngan dan ketinggalan ummat.

c. Ketiga, adanya pergeseran atensi (harapan, kepercayaan, minat, perhatian) masyarakat dan pemerintah dari kekuatan sosial politik praktis ke kekuatankekuatan sosial lain, yang diharapkan dapat menunjang kepentingannya (Pratiknya, 1994 : 1-2).

Selain itu, fenomena lain yang cukup menonjol di penghujung abad 20 dan memasuki abad 21, adalah pengaruh globalisasi juga memberikan warna tersendiri pada dinamika organisasi dan pergerakan Islam di Indonesia. Organisasi Islam yang telah mapan secara kultural, struktural maupun institusional yaitu Nahdhlatul Ulama dan Muhammadiyah harus siap bersaing dengan dinamika pergerakan Islam yang semakin berkembang dengan tumbuhnya pergerakan Islam yang mengadopsi atapun menyatakan sebagai bagian ataupun cabang dari organisasi Islam dari luar Indonesia. Diantaranya Hizbut Tahrir, Salafiyah, Jamaah Tabligh, Tarbiyah, ataupun gerakan bawah tanah Jamaah Jihad walaupun kurang menunjukkan eksistensinya dipermukaan (Trunojoyo, 12 Mei 2015).

Selanjutnya, pertengahan tahun 2001, nama "Islam Liberal" mulai dikenal luas di Indonesia. Nama itu menjadi perbincangan di tengah masyarakat. Khususnya kaum Muslim Indonesia. Dengan semboyannya yang indah menawan, "Islam yang membebaskan", kelompok yang kemudian mengusung bendera "Jaringan Islam Liberal" (JIL) berhasil menarik perhatian banyak kalangan, baik yang pro maupun kontra 9Husaini dan Hidayat, 2002: vii).

Dalam trend Islam awal abad 21, maka kita melihat bahwa ada beberapa kategori, yaitu cendekiawan Muslim, organisasi-organisasi, serta yang masih hangat dibicarakan hingga kini adalah JIL. Ketiga kategori tersebut saling berpacu memberikan pandangan-pandangannya tentang Islam kepada masyarakat. Di bawah ini akan dijelaskan beberapa kategori tersebut, antara lain:

\section{CENDEKIAWAN MUSLIM}

Cendekiawan (intelektual) ialah orang yang karena pendidikannya, baik formal, informal, maupun non-formal, mempunyai perilaku cendekia. Kecendekiaan ini tercermin dalam kemampuannya menatap, menafsirkan, dan merespon lingkungan hidupnya dengan sifat dan sikap: kritis, kreatif, objektif, analitis, dan bertanggung 
jawab. Karena sifat dan sikap tersebut, cendekiawan mempunyai wawasan dan pandangan yang tidak dibatasi oleh ruang dan waktu (Pratiknya, 1994: 3).

Cendekiawan Muslim, secara sederhana dapat dilukiskan sebagai Muslim, di samping memiliki kualitas perilaku cendekia seperti yang telah disebutkan,juga beriman dan senantiasa berkomitmen pada agama Islam sebagai pandangan hidupnya. Cendekiawan Muslim adalah mereka yang mempunyai kearifan yang tinggi dalam menatap, menafsirkan, dan merespons persoalan yang muncul pada kehidupannya, baik yang bersifat individual, masalah kemasyarakatan dan ummat maupun masalah kemanusiaan.

Dalam konteks keindonesiaan cendekiawan Muslim, di samping mengacu pada keberadaan mereka di Indonesia, terutama keterkaitan tanggung jawab mereka terhadap persoalan-persoalan yang dihadapi bangsa Indonesia. Dalam konteks tersebut, tidak mengurangi universalitas sifat kecendekiaan dan keulul-albaban mereka. Kontektualitas di sini berarti menyangkut medan dan permasalahan yang dihadapi serta menyangkut amalan atau karya kecendekiaan mereka, dan bukan menyangkut identitas kehidupan dan perilakunya sebagai Muslim yang cendekia (Pratiknya, 1994: 3-6).

Ada beberapa cendekiawan Muslim Indonesia yang cukup terkenal pada pertengahan hingga akhir abad 20, yaitu Harun Nasution dan Nurcholis Majid. Dua cendekiawan Muslim ini telah memulai gagasan pembaharuan dalam Islam di Indonesia pada tahun 1970-an (Assyaukani, 2007: 18).

Contoh lainnya cendekiawan Muslim Indonesia yang cukup terkenal pada abad 21, menurut penulis, adalah Azyumardi Azra. Beliau adalah seorang cendekiawan Muslim yang tak asing bagi kaum akademisi di Indonesia. Beliau merupakan orang yang telah berhasil merubah IAIN menjadi UIN, pada tahap selanjutnya perubahan ini juga diikuti oleh beberapa IAIN di tanah air. Banyak karya yang telah beliau hasilkan. dalam hal ini, penulis melihat karya-karya yang dihasilkan khususnya dalam bidang sejarah pemikiran Islam (Rais, 1994: 34).

\section{ORGANISASI-ORGANISASI ISLAM}

Pada awal abad 21 ini, kita bisa melihat pergerakan organisasi-organisasi Islam yang ada di Indonesia. Organisasi-organisasi Islam yang cukup terkenal antara lain:

\section{MUHAMMADIYAH}

Di antara gerakan-gerakan modernis Islam di seluruh dunia, Muhammadiyah adalah gerakan yang lebih hati-hati dan lebih lentur dalam menghadapi gelombang perubahan politik (Maarif, 1985:66). Pergerakan yang dilakukan oleh Muhammadiyah boleh dikatakan adalah perubahan reformatif. Dalam hal ini, perubahan sosial lebih dititik beratkan pada perubahan humanis, yaitu untuk membangun kesadaran individu dalam aspek manusiawi sebagai akar dari perubahan sosial yang hendak diwujudkan, sehingga juga disebut dengan perubahan sosial dengan kesadaran naif. Man power development menjadi sesuatu yang diharapkan untuk mewujudkan perubahan. Sedangkan secara struktural, mereka akan mengikuti 
pola dan struktur yang sudah ada dan dianggap sebagai sesuatu yang sudah baik, mapan dan benar dan akan berubah sesuai dengan karakter perubahan manusianya. Sehingga pandangan ini akan mengusahakan perubahan sosial secara reformatif.

Dengan program pendidikan dan amal Islam yang terkelola dengan baik dan dikembangkan secara progressif, organisasi ini berusaha untuk meningkatkan kesadaran dan kemampuan masyarakat dalam usahanya merealisasikan perubahan kehidupan sosial, ekonomi, pendidikan, politik yang lebih baik. Ini dibuktikan dengan kontribusi besar para tokohnya dalam usahanya ikut serta menentukan pondasi negara ini walaupun dalam tataran nasionalisme (Trunojoyo, 12 Mei 2015).

\section{NAHDATUL ULAMA (NU)}

Ada fenomena menarik sejak tahun 1980-an hingga tahun 2003, yaitu tumbuh suburnya kajian tentang NU dari berbagai kalangan, terutama para pemikir, ilmuwan, dan cendekiawan. Dalam rentang waktu tersebut, kajian mengenai organisasi ini lebih banyak dibandingkan dengan Muhammadiyah.

Di balik simbol "kaum sarungan"-nya yang mengesankan kekolotan, NU ternyata mampu meletupkan gairah karena di dalam tubuh NU banyak terjadi gesekan, benturan, pergulatan, perubahan, keragaman, dan dinamika. Citra NU yang tradisionalis, feodalis, dan konservatif kini bahkan mulai bergeser menjadi pluralis, transformatif, radikal, demokratis, bahkan liberal. Abdurrahman Wahid, salah seorang tokoh NU, ternyata berhasil menancapkan tradisi liberal, toleran, dan inklusif di tubuh NU. Kultur liberal ini, bahkan mulai merambah ke berbagai pesantren NU (Wahdi, 2004: 23).

NU kini merupakan ormas yang mempunyai stok pemikir-pemikir yang progresif, radikal, dan liberal. Maka tidak heran, jika tradisi intelektualitas dan pemikiran di tubuh NU terasa lebih segar, dinamis, penuh warna, dan mencerahkan. Perlahan tapi pasti ada perubahan-perubahan yang cukup progresif dan revolusioner dalam tubuh NU, terutama yang dimotori oleh para ulama, pemikir, cendekiawan, dan aktivis (khususnya kaum muda NU) yang kritis, radikal, progresif dan liberal(Wahdi, 2004: 24).

\section{HIZBUT TAHRIR}

Pergerakan Islam lain yang tidak menggunakan jalur kekerasan fisik tetapi dengan revolusi pemikiran yang bisa dikategorikan menganut paradigma perubahan transformatif revolusioner ini adalah Hizbut Tahrir. Sebagai pergerakan Islam yang mengklaim sebagai partai politik internasional yang berpusat di Yordania dan diisukan hijrah ke Inggris sebagai markas pusatnya ini menunjukkan geliatnya di negara-negara demokratis Eropa, sebagian Asia Tengah serta Indonesia. Wacana dan doktrin revolusi pemikiran pergerakan Islam ini dibangun dengan diskusi-diskusi, buku, booklet, ataupun selebaran-selebaran dialogis untuk memberikan pengaruh dan menanamkan keyakinannya kepada umat Islam untuk mengikuti pola pikir yang mereka anut, terutama dari golongan terdidik. 
Metode revolusioner dalam mewujudkan perubahan sosial yang ditempuh Hizbut Tahrir dapat dikategorikan dalam dua jalan utama. Jalan pertama untuk melakukan revolusi struktural adalah dengan merebut kepemimpinan yang mereka sebut dengan Thulabun Nusroh, atau pencarian perlindungan. Dengan jalan lobi-lobi dan diskusi politik dengan pemimpin-pemimpin negara, masyarakat ataupun keagamaan mereka berusaha memberikan pengaruh pemikiran, sehingga diantara para pemimpin itu bersedia untuk menempuh jalan dan cara pandang mereka untuk bersama-sama mereka mewujudkan terbentuknya daulah IslamKhilafah Islamiyah dan tegaknya syariat Islam. Sedangkan jalan yang kedua adalah dengan Ash-Shira' ul-Fikra untuk melakukan revolusi sosial, yaitu dengan memberikan pengaruh pemikiran secara luas kepada masyarakat bawah dengan cara menghancurkan wibawa pemerintahan, dan mempertontonkan kekurangan, kegagalan ataupun kebobrokankebobrokan kepemimpinan negara serta menganggap seluruh pemerintahan negerinegeri Islam saat ini adalah Darul Kufr alias dianggap Negara kafir. Hal tersebut bertujuan untuk menghilangkan kepercayaan masyarakat pada pemimpin-pemimpin pemerintahan terutama negeri-negeri Islam, sehingga pada akhirnya akan mampu menggerakkan masyarakat untuk bersedia bergerak bersama HTI melakukan revolusi terhadap rezim yang berkuasa (Trunojoyo, 12 Mei 2015).

Di Indonesia, HTI berusaha untuk menerapkan syari'at Islam. Karena penerapan hukum yang di adopsi dari Syariat Islam tidaklah bertentangan dengan keutuhan NKRI dan Pancasila. Perjuangan yang mereka lakukan tanpa mengenal lelah dan henti. Mereka tidak bosan-bosan memberi masukan kepada pemerintah, DPR/MPR untuk semaksimal mungkin menerapkan syariat Islam di negara ini (Adminbrabo, 12 Mei 2012)..

Menurut penulis, Hizbut Tahrir Indonesia (HTI) telah banyak melakukan kiprah di tengah-tengah masyarakat Indonesia, contohnya memasuki kampus-kampus dan melakukan kegiatan-kegiatan berupa training motivasi, serta melakukan diskusidiskusi keIslaman. Dalam kehidupan masyarakat, yang penulis lihat kiprah HTI lebih menyuarakan penegakan khilafah yang merupakan solusi berbagai permasalahan yang dihadapi negeri ini, seperti demo tanpa anarkis dalam mengkritik pemerintah, serta menyebarkan buletin mingguan bernama Al-Islam dan menerbitkan tabloid dwi mingguan yaitu Media Ummat. Dari usaha ini diharapkan masyarakat negeri ini terbuka mata dan pikirannya untuk melihat permasalahan yang dihadapi serta berusaha untuk mencari solusinya.

\section{SALAFIYAH}

Pola gerakan salafiyah dalam pergerakan Islam adalah perubahan pasif dan dominatif. Golongan ini lebih dekat dengan kelompok Islam yang hanya menyandarkan orientasi gerak dibidang ubudiyah. Dalam hal ini perubahan sosial tidak mampu mengetahui hubungan atau kaitan antara satu faktor dengan faktor lainnya untuk melakukan perubahan sosial secara humanis maupun struktural untuk mewujudkan perubahan tatanan sosial secara global (Trunojoyo, 12 Mei 2015). 
Menurut penulis gerakan salafiyah yang lebih berorientasi kepada ubudiyah, tidak akan mampu merubah struktur sosial dan kehidupan masyarakat secara luas. Artinya, gerakan ini hanya lebih difokuskan intern sesama anggota salafiyah. Boleh dikatakan bahwa gerakan ini tidak membahas politik dalam kehidupan mereka.

\section{JAMAAH TABLIGH}

Jamaah Tabligh sangat berkembang di Indonesia karena gerakan ini menjauhkan diri dari dunia politik dan kontroversi-kontroversi politis. Kelompok ini merupakan gerakan penyebaran agama Islam yang berusaha terus menerus merekrut anggota dengan jalan persuasif. Jamaah Tabligh mampu membuktikan bahwa Islam adalah agama yang cinta damai.

Metode dakwah yang digunakan untuk menyeru manusia kepada Islam terbilang sederhana. Caranya, dengan mengorganisasi unit-unit tabligh yang terdiri atas sekurang-kurangnya sepuluh orang dan mengirim mereka ke berbagai kampung. Unit-unit tabligh itu, dikenal sebagai halaqah (kelompok). Mereka akan mengunjungi sebuah kampung, mengundang kaum Muslim setempat untuk berkumpul di masjid atau suatu tempat pertemuan lainnya. Mereka mendakwahkan Islam kepada masyarakat tanpa mempersoalkan aliran, mazhab, dan khilafiah 9Suprayetno, (Diakses 18 Mei 2012).

Menurut penulis, boleh dikatakan bahwa gerakan yang dilakukan oleh Jama'ah Tabligh pada abad ini cukup berhasil merebut hati masyarakat Indonesia, yang pada saat ini banyak dilanda masalah. Dengan metode dakwah yang dilakukan, mampu menyentuh hati dan bentuk aktifitas keagamaan yang dibudayakan Jama'ah Tabligh merupakan salah satu bentuk terapi kesehatan jiwa.

\section{TARBIYAH}

Pergerakan Islam Tarbiyah merupakan pergerakan Islam yang cenderung menggunakan pendekatan paradigma perubahan sosial seperti Muhammadiyah. Gerakan ini memiliki orientasi utama untuk membangun konsep dan struktur berdasarkan Islam dalam semua bidang dengan jargonnya AlIslam huwal Hal dan dengan cakupan global, yang mereka sebut dengan Ustadziatul 'Alam. Namun dalam tataran geraknya mereka menggunakan tahapan-tahapan perubahan yang disebut dengan Mihwar. Sehingga gerakan ini cenderung untuk melakukan perubahan secara humanis dan reformatif Islam.

Pergerakan Islam ini cukup menarik untuk dicermati karena pengaruhnya yang berkembang secara signifikan. Dalam tatanan reformasi politik, pergerakan ini membangun sayap politiknya melalui Partai Keadilan yang kemudian berubah menjadi Partai Keadilan Sejahtera, saat ini memiliki kemampuan politik yang cukup signifikan sebagai kekuatan partai Islam terbesar. Begitu pula dalam pengembangan amal Islam keagamaan, pendidikan, kesehatan dan bidang sosial lainnya dengan pendirian pesantren, sekolah Islam, lembaga sosial dan zakat serta berbagai misi sosial dan kesehatan ataupun budaya yang cukup mewarnai. Dalam pembangunan SDM, pergerakan Islam ini juga cukup dominan memberikan warna keislaman di 
lembaga-lembaga pusat pendidikan tinggi serta lembaga riset IPTEK nasional (Trunojoyo, loc.cit.).

Penulis melihat, bahwa kelompok Tarbiyah di Indonesia umumnya, dan Sumatera Barat khususnya, telah memperlihatkan pengaruhnya. Hal ini terlihat dari Pemilukada Gubernur yang dilakukan tahun 2010, berhasil dimenangkan oleh PKS, dengan terpilihnya Prof. Dr. Irwan Prayitno sebagai gubernur Sumbar. Sedangkan di dunia kampus, alumni dari Madrasah Tarbiyah Islamiyah (MTI) Candung, Prof. Dr. Makmur Syarif telah mampu menduduki kursi Rektor IAIN Imam Bonjol Padang, dan Prof. Dr. Awis Karni menduduki jabatan sebagai direktur Programa Pascasarjana IAIN IB.

\section{JAMAAH JIHAD}

Jamaah Jihadmerupakan gerakan yang melakukan perubahan secara tranformatif. Dalam hal ini perubahan sosial dibangun dengan kesadaran kritis revolusioner. Salah satu strategi dasar adalah contending (bertanding) yaitu mencoba menerapkan solusi yang lebih disukai oleh salah satu pihak atas pihak lain (Pruitt dan Robin, 2009: 4).

Untuk saat ini, meskipun masih belum signifikan pengaruhnya tetapi pergerakan Islam revolusioner Jamaah Jihad, dalam hal ini bisa terwakili oleh Majelis Mujahidin dan Ansharuttauhid. Jika kita lihat dalam sejarah panjang pergerakan Islam nasional, pergerakan Islam seperti ini sebenarnya memiliki akar sejarah yang cukup signifikan di Indonesia. Dengan latar belakang Gerakan Darul Islam DI/TII yang didirikan KartoSuwiryo pada tahun 1947, yang mampu memberikan perlawanan dengan pemberontakan yang terbesar dan terlama dalam masa-masa revolusi. Selain di sebagian Jawa Tengah dan Jawa Barat, gerakan ini juga berkembang dengan NII yang berkembang di Aceh, Sulawesi Selatan dan Tenggara serta Kalimantan Selatan, sehingga pemberontakan untuk mendirikan Negara Islam untuk melawan pemerintahan RI dan menggantikan bentuk Negara nasionalis NKRI ini mampu bertahan tidak kurang dari 15 tahun.

Dalam bentuk perlawanan yang lebih dapat dipandang vandalisme saat ini, sisasisa NII yang mengatas namakan JI(Jamaah Islamiyah) ataupun Al-Qaedah Indonesia, dengan pengaruh organisasi Jihad luar negeri mereka seolah-olah mendapatkan ruh baru. Dengan mengadopsi pemikiran fundamentalisme ideologis Jamaah Islamiyah yang berkembang di Mesir yang kemudian melakukan tranformasi kedalam jaringan Al-Qaedah, sempalan pergerakan organisasi jihad internasional ini ingin menunjukkan eksistensinya dengan berbagai serangan teror terhadap kepentingan-kepentingan asing di negeri ini. Selain itu dalam pandangan mereka, pemerintahan yang tidak berdasarkan ideologis dan hukum Islam adalah wajib dihancurkan dan diperangi (Trunokoyo, Loc.Cit).

Penulis melihat bahwa Jama'ah Jihad merupakan gerakan Islam aliran keras. Hal ini disebabkan kelompok ini menginginkan perubahan yang cepat, sehingga untuk mencapai tujuannya mereka menggunakan jalan kekerasan ketika jalan damai sudah tidak mampu lagi digunakan oleh mereka. 


\section{JARINGAN ISLAM LIBERAL}

Wacana dalam pembaharuan Islam pertama kali dipelopori oleh Nurcholis Madjid (murid dari Fazlur Rahman di Chicago), dan Harun Nasution (lulusan Mc. Gill University Kanada), disamping terdapat juga tokoh-tokoh lain saat itu, seperti Djohan Efendi dan Ahmad Wahib. Nurcholis Madjid telah memulai gagasan pembaharuannya sejak tahun 1970-an. Pada saat itu, Nurcholis Madjid telah menyuarakan pluralism agama. Nurcholis mempromosikan gagasan-gagasannya ke masyarakat kelas menengah ke atas lewat institusi Paramadinanya.

Sedangkan Harun Nasution berhasil mempengaruhi institusi perguruan tinggi Islam, setelah tahun 1973, bukunya Islam ditinjau dari berbagai aspek ditetapkan sebagai buku utama mahasiswa IAIN se-Indonesia. Buku yang diterbitkan pertama kali tahun 1974 itu, dijadikan behan bacaan pokok untuk mata kuliah "Pengantar Ilmu Agama Islam", melalui rapat kerja Rektor IAIN se-Indonesia di Ciumbuluit Bandung tahun 1973. Dengan demikian dapat dikatakan bahwa Nurcholis Madjid dan Harun Nasution merupakan "pioner" pertama dalam melahirkan faham pembaharuan Islam di Indonesia, karena melalui keduanyalah wacana meliberalkan Islam dikenal di Indonesia (Lutfie Assyaukani, 18).

Seiring berjalannya waktu, ide-ide Nurcholis dan Harun selanjutnya dikembangkan oleh kader-kader godokan keduanya, sehingga pada akhir tahun 1990 muncullah sekelompok anak muda yang menamakan diri kelompok "Islam Liberal" yang mencoba memberi respon terhadap permasalahan -permasalahan yang muncul pada akhir abad ke-20. Latar belakang kemunculan gerakan ini adalah untuk menolak Islam garis konservatif yang jumud dan beku menurut mereka untuk menampilkan Islam dengan wajah baru (Muhtadi, 2006:9).

Kondisi inilah kemudian mendorong beberapa aktivis muda untuk melakukan berbagai diskusi di Jalan Utan Kayu 68 H Jakarta Timur. Kemudian dengan merujuk kepada tempat itulah maka beberapa tokoh muda Islam mendirikan Komunitas Utan Kayu yang merupakan cikal bakal berdirinya Jaringan Islam Liberal (JIL). Beberapa nama yang terlibat untuk membentuk Komunitas Utan Kayu itu dan kemudian mendirikan JIL antara lain Ulil Abshar abdalla, Nong Darul Mahmada, Burhanuddin, Ihsan Ali Fauzi, Hamid Basyaib, Taufiq Adnan Amal, Saiful Mujani dan Luthfi Assyaukanie.

Selanjutnya secara lebih nyata para anak-anak muda tersebut mendirikan sebuah jaringan kelompok diskusi pada tanggal 18 Maret 2001, yang tujuannya adalah untuk kepentingan pencerahan dan pembebasan pemikiran Islam Indonesia. Usahanya untuk menyebarkan ide-ide dan gagasannya dilakukan dengan membangun milis (Islamliberal@yahoo.com) dan website http//:www.islamlib.com. Sejak saat itulah mereka mendeklarasikan diri dengan sebutan Jaringan Islam Liberal. Kegiatan utama kelompok ini adalah berdiskusi tentang hal-hal yang berkaitan dengan Islam, negara dan isu-isu kemasyarakatan.

Melalui milis dan website mereka inilah, ide-ide liberalisme dan kontekstualisasi Islam tersebut disosialisasikan dan diwacanakan ke publik. Wacana- 
wacana yang dipublish serta disosialisasikan tersebut juga berhubungan dengan isuisu yang berkaitan dengan fenomena sosial yang terjadi dari waktu ke waktu.

Dari beberapa bentuk gerakan Islam di Indonesia pada abad ini, baik yang individual maupun organisasi, secara umum ingin mengajak umat Islam untuk kembali dan mendalami ajaran Islam, selain itu juga untuk menunjukkan kepada dunia bagaimana karakter dari Islam di Indonesia. Walaupun terjadi beberapa perbedaan dalam metode yang digunakan, namun hal itu menjadi dinamika intern Islam di Indonesia. Pada tahap selanjutnya, hal ini akan terus berlanjut demi mewujudkan umat Islam yang berkualitas.

\section{KESIMPULAN}

Di penghujung abad 20 dan memasuki abad 21, trend baru Islam di Asia Tenggara umumnya, dan Indonesia khususnya telah banyak mengalami perubahan. Perubahan itu ditandai dari gerakan-gerakan yang dilakukan oleh berbagai organisasi Islam. Ada yang berhaluan keras, lembut, atau berada di antara keduanya. Organisasi-organisasi Islam ini saling berpacu antara satu sama lain dalam merebut hati masyarakat serta menunjukkan keeksistensiannya di tengah kehidupan berbangsa dan bernegara.

Di Indonesia banyak sekali organisasi yang ingin menjatuhkan satu sama lain sehingga masyarkat susah membedakan antara organisasi mana yang benar atau yang sekedar mencari panggung. Pada hakikatnya semua organisai tersebut ingin mengembalikan Islam seperti semula seperti konsep khilafah yang diajukan oleh Hitbur Tahrir (HTI) kepada pemerintah. Namun sebagian dari mereka juga ada melakukan perubahan dengan cara kekerasan dan terlalu memaksakan kehendak contohnya seperti salah satu organisasi Jama'ah Jihad.

Akibat perbedaan tersebut menimbulkan berbagai perpecahan dari reaksi masyarakat yang setuju dan yang tidak setuju. Maka jika mereka dipertemukan dalam suatu forum, mereka akan saling menjatuhkan dan menganggap hanya merekalah yang paling benar.

\section{DAFTAR PUSTAKA}

Assyaukani, Lutfie, Kontekstualisasi Khazanah Islam Klasik Indonesia, Jakarta: Komunitas Utan Kayu, 2007.

Cipto, Bambang, Dunia Islam dan Masa Depan Hubungan Internasional Abad 21, Yogyakarta: LP3M UMY, 2011.

Gottschalk,Louis,Mengerti Sejarah, Penterjemah Nugroho Notosusanto. (Jakarta: Universitas Indonesia Press, 1985.

Hidayat, Adian Husaini dan Nium,Islam Liberal: Sejarah, Konsepsi, Penyimpangan dan Jawabannya, Jakarta: Gema Insani, 2002.

Kartodirdjo,Sartono,Pendekatan Ilmu Sosial Dalam Metodologi Sejarah, Jakarta: Gramedia, 1993.

Kuntowijoyo, Metodologi Sejarah, Bandung: Tiara Wacana, 2003. 
Maarif,Ahmad Syafii,Studi Tentang Percaturan Dalam Konstituante: Islam Dan Masalah Kenegaraan, Jakarta: LP3ES, 1985.

Muhtadi, Asep Saiful,Pergulatan pemikiran Politik Radikalisme dan Liberalisme Islam Indonesia, Jakarta: LP3ES, 2006.

Rais, M. Amien (Ed), Islam Di Indonesia: Suatu Ikhtiar Mengaca Diri, Jakarta: PT. Raja Grafindo Persada, 1994.

Rubin,Dean G. Pruitt dan Jeffrey Z.,Teori Konflik Sosial, (penterjemah: Helly P. Soetjipto dan Sri Mulyantini Soetjipto), Yogyakarta: Pustaka Pelajar, 2009.

Wahid, Marzuki (Ed), Jejak-Jejak Islam Politik: Sinopsis Sejumlah Studi Islam Indonesia, Jakarta: DITPERTAIS Depag, 2004.

Wahyudi (2019). Naskah Muqaddimah Al-Mubtadin, (Jakarta: Perpustakaan Nasional Republik Indonesia.

Website:

Adminbrabo, Islam Radikal di Indonesia, http://sirojuth-tholibin.net/2012/03/sekilastentang-wahabi/. Diakses tanggal 18 mei 2012.

Dalam Dakwah, Menjadi Gerakan Islam Terbesar Tanpa Banyak Omong,http://dalamdakwah.wordpress.com/2012/04/11/menjadigerakan-islam-terbesar-tanpa-banyak-omong/\#more-635. Diakses tanggal 16 Mei 2012.

Suprayetno, Aplikasi Ajaran Al-Qur'an di Alam Dunia, http://daarulhuda99.blogspot.com/?zx=d654eeebeb8cd1c0. Diakses tanggal 18 mei 2012.

Trunojoyo, Peta Pergerakan Islam di Indonesia Abad 21, http://oase.trunojoyo.ac.id/index.php/tatsqif/60-harakah/139-pergerakanislam. Diakses tanggal 15 mei 2012. 